\title{
Comparative Pragmatic Study of Print Media Discourse in Baluchistan Newspapers Headlines
}

\author{
Muhammad Ramzan', Hira Jalil Awan', Muhammad Ramzan ${ }^{3,}$ Hurria Maharvi $^{4}$ \\ 1M Phil Linguistic Lahore Leads University Lahore. \\ 2 M Phil Linguistic Islmia University Bhawalpure. \\ 3 M Phil Literature Foundatonis University Islamabad. \\ 4 M Phil Linguistic Government Saqiq College Women University Bhawalpure.
}

To cite this article: Muhammad, R. et al. (2020) Comparative Pragmatic Study of Print media discourse in Balochistan newspapers headlines, Al-Burz, Volume 12, Issue 01

Received: December 10, 2020; Accepted: December 18, 2020; Published: December 31, 2020

\section{KEYWORDS}

Pragmatic,

Print Media

Discourse

Baluchistan,

Headlines

\section{ABSTRACT}

In the last two decades the power of mass media has influenced the society and recently, the public interest for media activities has increased tremendously. Similarly, in this advanced technological age, many jobs are associated with media coverage, for example, military actions, affiliation of public with political and social activities, and intentions, actions and attitudes of community etc. For the transmission of these actions in news and newspapers headlines, powerful and influencing strategies are adopted in the use of language. Many characteristics of language are determined through its use and one of them is known as pragmatic approach. But, in Baluchistan context neither, an appropriate focus is provided to research study for pragmatic analysis nor is Searle's taxonomy of speech acts studied in Baluchistan newspapers headlines. In this research, efforts have been made to fill up this gap in existing literature. The sample of study is selected from three Baluchistan newspapers i.e. Express (Quetta), Baluchistan Times and Talar (Noshkay) headlines. Forty news headlines are taken from selected three newspapers. Almost all the news statements are obtained from front pages and these headlines are analyzed in the light of Searle's taxonomy of speech acts. The findings of study suggest that Searle's taxonomy of speech act is applicable to selected Baluchistan newspapers headlines and statements are loaded with different intended meanings. The statistical analysis of the study reveals the effective employment of Representatives (assertives) speech acts in newspapers headlines. In conclusion it can be suggested that there might be specific intentions of the speakers in the news headlines.

\section{Introduction}

The power of mass media for the last few decades has been considerably influencing our lives directly or indirectly, so the role of media discourse has become very significant in the lives of people. TV news channels and news headlines in different newspapers are very active in performing various functions e.g. ideological stance, power relations and manipulative agendas at the same time when the readers and viewers want to know about the current situations of society and world. Alternatively, certain motives are achieved through the manipulated and manufactured agendas in 
the transmission of news and newspapers headlines. Similarly, attention of readers is drawn and attracted by the editors of newspapers and owners of TV channels through distracting their thoughts towards the specific news for the achievements of their own motives. In the language of headlines, various linguistic and pragmatic devices are used for manipulation and function of headlines is described and explained in the text in different ways. The language of headlines is known as a distinctive type of text. Some functions of headlines are wrapped in the text, and these are helpful in filling the shape of text e.g. structure and context (Reah. 2002). Dor (2003.720) moves further and claims that, in addition to the semantic and pragmatic functions, it is "a communicative device whose function is to produce the optimal level of affinity between the content of the story and the readers' context of interpretation." The production of news is influenced by the media organization as a main goal. In this regard, Fowler (1991.12) emphasizes that it is "a systematic sorting and selecting of events and topics according to a socially constructed set of categories." Stressing the role of discursive strategies in enhancing newsworthiness of the reported events, Bednarek and Caple (2012. 44) add that "Newsworthiness is not inherent in events but established through language and image." Headlines have different functions (Bell 1991.189). for example, distinguishes between the functions of headlines and he says headlines always give "abstract the main event of the story" and "headlines which focus on a secondary event or a detail." (Crystal and Davy, 1969.146). refer to the complicated nature of function of headlines "Headlines have to contain a clear, succinct and if possible intriguing message, to kindle a spark of interest in the potential reader...whose eye moves swiftly down a page and stops when something catches his attention." Headlines perform three functions. They provide summary of the news, attract attention, and work an initial indicator of news value (Conboy, 2007.13).

The information is covered by the news headlines and the interest of the powerful people can be associated in the news headlines or powerful people are influenced by the news headlines (Reah, 1998). The few words in the news headlines are enough to explain this complexity. It gives brief detail there or it develops curiosity for the viewers that is explained in news headlines (Ungerer, 2000). It is clarified by Develotte and Rechniewski (2001) that headlines are the symbols of news and they further explain that these are more significant for viewers/readers as compared to the news articles in the sense that social, national and cultural representations are reflected by the news headlines. In the news headlines, the choice of linguistic items is pre requisite for the creation of influence over the readers and to direct their attention to the various episodes. In the news headlines, the attitudes and opinions of editors are manifested regarding the agenda of news and the explanation of transmitted attitudes and opinions in the news headlines can be revealed with the help of linguistic analysis. Likewise, the intentions of headlines are sustained and initiated through the representation of pragmatic analysis. Thus Chiluwa (2007, p.70) explains that a very important and key role is played by the pragmatic analysis in the headlines because writer's intention is always placed on pragmatic meanings in the news. However, the primary aim of the language is communication but it is also important point to know in language that how the ideas are shaped by the use of language. It is very prominently known that speech acts theory is a pragmatic component of language and the identification of speech acts will be helpful to the reader and listener to understand the meaning which is not said explicitly. It is observed that existing literature in Baluchistan context is lacking the research study for pragmatic analysis in newspapers headlines, and furthermore Searle's taxonomy of speech acts is hardly analyzed there. In this research it is endeavored to fill up this gap in existing literature. The sample of study is selected from the headlines of three Baluchistan newspapers i.e. Express (Quetta), Baluchistan Times and Talar

\section{Methodology}

The data is collected from the three newspapers headlines i.e. Express (Quetta), Baluchistan Times and Tular newspapers and all these three data newspapers are selected from Baluchistan domain. Selected headlines and statements from front pages are considered for research study. The selection of the data is made by giving the focus to the main headlines and renowned personalities' statements. The sample of the study is designed by taking forty statements of news headlines from each newspaper randomly i.e. Express (Quetta), Baluchistan Times and Talar newspapers. 
The sample is analyzed by using the Searle's (1979) taxonomy of speech acts taking as a research tool. The statements of all newspapers are investigated quantitatively. These news headlines of all newspapers are classified according to the above mentioned taxonomy of speech acts statistically in the present research paradigm and finally it is seen the overall use of performative also.

\section{Literature Review}

\section{a. Previous Studies}

After the detailed study of related literature, it becomes clear that mostly in previous researches basic focus was on rhetoric analysis and stylistic views in news headlines. Initially, Taiwo (2007) investigated the use of Nigerian Newspapers Headlines that how they played a role to shape the ideologies and realization of power relations. The previous studies of news headlines are Muhammad's (2005) A Pragmatic Analysis of Selected English Political Newspapers Headlines, Siposova,s (2011) Headlines and Sub headlines Tense: Modality and Register Based on Discourse Analysis of The British Tobloid, The Sun, which focuses on Critical Discourse Analysis to identify the ideologies. Abba and Musa's (2015) Speech Act Analysis of Daily Trust and The Nation Newspapers Headlines Reports on "Boko Haram" Attacks investigate major speech acts. It also analyzes the associations of implied meaning with the speech acts. Finally, it is revealed in the findings that assertive speech acts dominate in the news headlines and aim of the speech acts is not threatening, advising and frightening. Parkash and Dhawan's (2017) Linguistic Divergence in Newspapers Headlines and Roya's (2017) The Rhetoric of Persian News Headlines: A Case Study of Euro news, are renowned researches. However, there are few a studies that ponder over the headlines of news channels e.g. Rustam's (2013) Pragmatic Analysis of CNN Headlines by using pragmatic and linguistic devices representing Pakistan. It was conducted by describing the identification of illocutionary acts. There is also Hameed Ali and Hamood Ali's (2018), A Pragmatic Study of CNN and BBC News Headlines Covering the Syrian Conflict focusing on speech act analysis. Finally, it is Khalid Jabbar and Tuama Jasim's (2020), A Pragmatic Study of Newspapers Headlines in Media Discourse: Iraq as a Case Study which investigates Searle's Taxonomy of speech act. Besides pragmatic analysis, Ismail (2016) talks about the semantics and pragmatics interrelationship of BBC news headlines focusing on Crimea crisis of Ukraine. Emphasis is given to the misunderstanding and misconception between speakers and hearers and presupposition and entailment are used as a research tools.

\section{b. Analytical Framework of the Study}

John Austin focuses on the theory of speech acts in his lectures and which were published in 1962 under the title How to do Things with Words posthumously. After his death, the ideas were adopted by his students for their development. Searle asserts that speech act is an attempt at doing something purely by the words or actions performed via utterances are generally called speech acts for which social conventions and institutions are required (Huang, 2007). According to Austin (1992, p.101) there are three types of speech acts.

a: Locutionary Act: Actual utterances and their ostensible meanings.

b: Illocutionary Act: The real meanings that speakers intend.

c: Perlocutionary Act: The actual effects of speech acts, whether was intended by the speaker or not.

Speech acts are grouped in five types by Austin (1962) i.e. vindictive, exercitives, comissives, expositives and behatitives (Hameed \& Hamood 2018). Searle (1969.16) describes that the smallest unit of communication is called speech act. However, there are various micro classes of this unit which are further classified in the mini micro classes that grants a taxonomy of speech acts refined by Searle (1975,79.12-20). He describes and lists five types of speech acts taxonomy: representatives or assertives, directives, declaratives, expressive and comissives.

\section{Asseratives or Representatives:}

Asseratives or representatives are the speech acts that commit the speakers to the truth of proposition or something being the case. Huang (2007) gives the catalogue of verbs which express the asserative or representative speech acts which assert report, conclude state and claim. Hameed \& Hamood (2018) say that assertaive speech acts are obligated by the addressor to inform about the truth.

Examples:

"Corresponding Author: Tel:+92-321-982-4948; Email Address: ramzanmalik122@gmail.com 


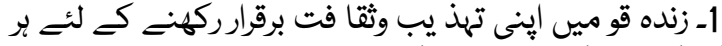

ممكن كوش شش كرتي بيي-جام كمال

2. Baluchistan's rights need practical steps. CM Kamal

3-استاد آتا كُداراج انا شواندرى ثُى ابم بنداس تخكى اسد قيصر

اردوترجمه: اساتذه كا كردارمعاشر ــ كى ترقى مي ايك ابم

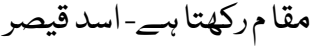

Directives: Directives speech acts are those speech acts that cause the hearers to do something for example order request and command etc. Huang (ibid) also provide the list of directives speech act. These speech acts are advice, command, order, request and question etc. In this type of speech acts the desire of addressor for addressee to do some actions is expressed. (Khalidand Tuama, 2020).

\section{Examples:}

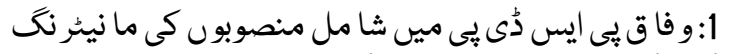

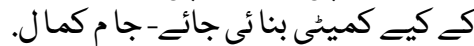

2. Germany urges Pak India to resolve issues through dialogues.

$$
\begin{aligned}
& \text { 3: سر كارى ا دا ره غاتـــ امر كه مر ـــ الس نا خزمت نا يا بند. }
\end{aligned}
$$

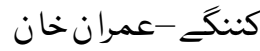

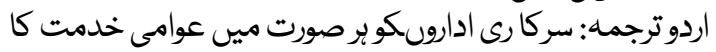

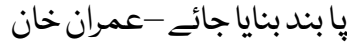

Comissive: Comissive speech acts commit the speakers to do something in the future. The verbs used in comissive speech acts reflect pledge, promise, and refusal and threat. This category of verb is used in changing the world (Khalid and Jasim 2020).

Examples:

1. بلوجستتان كوعا لمى قوتون كىيلغارسـ بجانا بو كا_مالكى بلو ج

2. PM promises towards development opportunities in tribal districts.

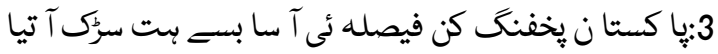

$$
\begin{aligned}
& \text { ييش تمنه -نوازشريف }
\end{aligned}
$$

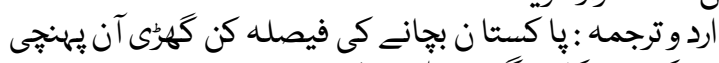

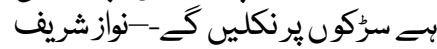

Expressive: Expressive speech actsexpress the speaker's feelings towards something. Huang (ibid) has also mentioned that psychological feelings and attitudes of addressor are expressed in expressive speech acts. These speech acts always show pleasure, sadness, liking and disliking. (Hameed \& Hamood 2018) have listed the expressive speech acts e.g. apologize, blame, congratulate, praise, welcome, condole and thank.

\section{Examples:}

$$
\begin{aligned}
& 1 \text { :كا ش عمر ان خان كا لعد م تنظيمون كـ ليح سخت لب و }
\end{aligned}
$$

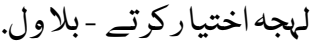

2:Germany appreciates Pakistan efforts for restoring peace in Afghanistan.

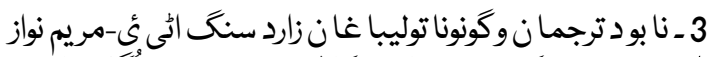

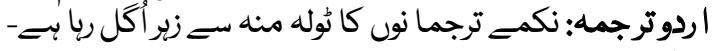

$$
\begin{aligned}
& \text { مريم نواز }
\end{aligned}
$$

Declarative: Declaratives speech acts are known to have a capability of changing the reality and these speech acts always change the condition or status of referred entities. The verbs used in this kind of speech acts are mainly declarative.

\section{Examples}

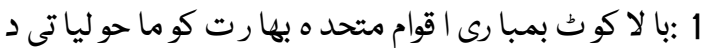

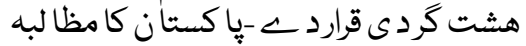

2: US Newspapers name PM Imran Khan in the list for peace prize.

\section{Research Hypothesis:}

1. Assertives or Representatives are more commonly used in Baluchistan Times, Tular(Noshkay) and Express Quetta News Headlines.

2. Declarative are very rarely used in Baluchistan Times,Tular (Noshkay) and Express Quetta News Headlines.

3. Explicit speech acts are more frequently occurring in Baluchistan Times,Tular (Noshkay) and Express Quetta News Headlines as compared to implicit speech acts.

4. The study of speech act is most valuable research for language analysis headlines in Baluchistan context.

Research Questions: The intended questions to be replied in this research article are formulated as under.

Which kinds of speech acts are used in Baluchistan Times Newspapers headlines?

Which kinds of speech acts are used in Express (Quetta) Newspapers headlines?

"Corresponding Author: Tel:+92-321-982-4948; Email Address: ramzanmalik122@gmail.com 
Which kinds of speech acts are used in Talar (Noshkay) Newspapers headlines?

Which kinds of speech acts are prevalent in the headlines of Express (Quetta) Newspapers, Baluchistan Times and Talar (Noshkay) Newspapers headlines?

Which kind of Performatives E.g. Implicit or Explicit is dominating in the headlines of Express (Quetta) Newspapers, Baluchistan Times and Talar (Noshkay) Newspapers headlines as a pragmatic strategy?

\section{Aims of the Study}

The present study is designed to find out the types and use of speech acts which have been employed in Express (Quetta) ,Baluchistan Times and Tular newspapers. It is also highlighted the ways that how the discourse in headlines is presented and pragmatic devices are used to attract the reader's interest. Finally, it is endeavored to segregate the implicit and explicit speech acts to know the intentions of editors in Express (Quetta, Baluchistan Times and Talar newspapers

\section{Data Analysis}

The sample of the study in the newspapers headlines after investigating the data quantitatively justifies that speech acts are used in the selected statements. These speech acts can be categorized according to the classification given in taxonomy by Searle (1979). The statistical pragmatic analysis in the light of purposed model is shown in Table one and Figure one. The Table 1 and figure 1 explains that micro types of speech acts are used by the speakers in Express (Quetta) Newspapers headlines according to their intentions and their frequencies. The analysis shows that the highest frequency of speech acts used in Express (Quetta) newspapers headlines is representatives (Assertives), which are 24 in figure and 60 in percentage. Majority of representative speech acts employed in Express (Quetta) newspapers headlines are with verbs. Furthermore, the illocutionary force of speech acts to describe the intentions of editor for the readers about events has been described in the news agenda. Representative or assertive speech acts are used to show the present circumstances and situations. Then in Express (Quetta) newspapers after representatives' speech act, the commissive speech acts are standing at second highest ranking. These speech acts are 7 in frequency and their percentage is $17.5 \%$. Generally, commissive speech acts are known for the obligation and here in the newspapers headlines politicians, renowned personalities and different entities are presented describing about future actions. According to percentage and frequency expressive speech acts are at third numbers in Express (Quetta) newspapers headlines. These are 6 in frequency and 15 in percentage. In expressive speech acts, the emotions and psychological conditions are presented and this low percentage level of expressive speech act may indicate that minimum worth is given to psychological attitude and generally unbiased viewpoints are adopted in the news headlines. Directive speech acts show the ratio of fourth number with frequency of 3 and 7.5percentages. The directive speech acts illustrate the order, command and obligations. The low level of frequency for directive speech acts may suggest that it is impossible for the editors to give the orders frequently in news headlines. Declarative speech acts are not employed in Express (Quetta) newspapers headlines. It may be due to the fact that these speech acts are used to change the situations or circumstances and editors of the news are not so much authoritative to change the reality.

Analysis of Speech Acts in Express (Quetta) Newspapers Headlines

\begin{tabular}{|l|l|l|}
\hline $\begin{array}{l}\text { Speech Act } \\
\text { Type }\end{array}$ & Frequency & Percentage \% \\
\hline $\begin{array}{l}\text { Representatives } \\
\text { or Assertives }\end{array}$ & 24 & $60 \%$ \\
\hline Comissives & 07 & $17.5 \%$ \\
\hline Expressives & 06 & $15 \%$ \\
\hline Directives & 03 & $7.5 \%$ \\
\hline Declaratives & 0 & $0 \%$ \\
\hline
\end{tabular}

Table No. 1:

Statistical Analysis of Searle's Taxonomy of Speech Acts in Express (Quetta) Newspapers Headlines

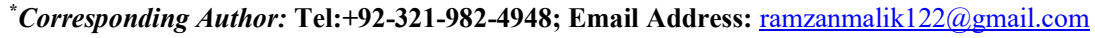




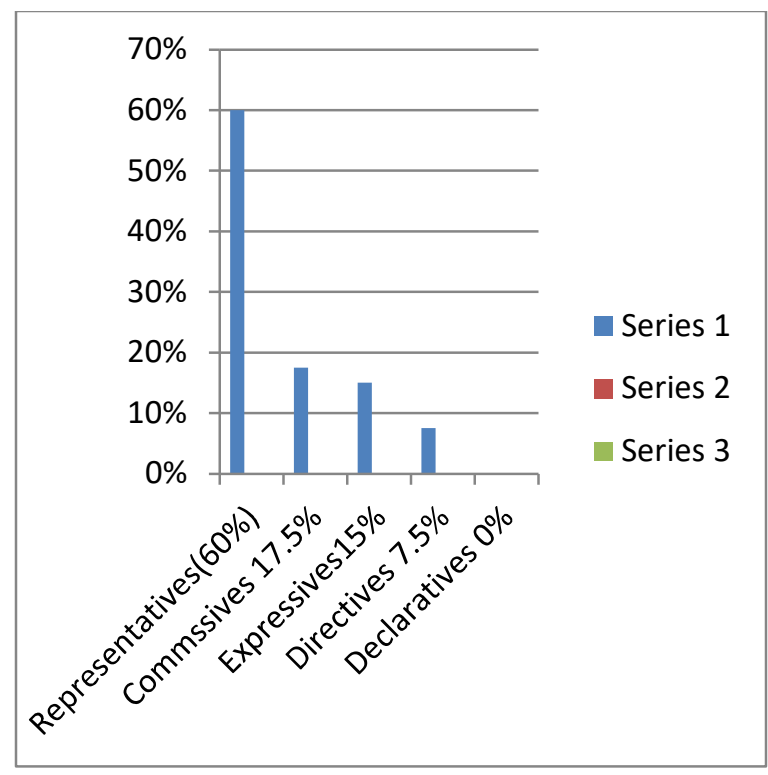

Figure: 1:

As exemplified in the figure two and table two the results of analysis suggest that in Baluchistan Times newspapers headlines representative (assertive) speech acts are again standing at highest ranking in percentage used in this newspaper headlines also. Majority of representatives' speech acts employed in Baluchistan Time newspapers headlines are with verbs but there are also a few verbs less. Likewise, the illocutionary force of speech acts about the description and performance of events have been exercised in the news headlines to notify the reader. Statistical data reveals the frequency of representative speech acts 24 and 60 percents, representing. Representatives or assertives are used most frequently that they specify the present circumstances and describe current affairs. So, it is concluded that editors in the news just try to present headlines with the help of spokesmen because representatives' speech acts express the proposition in news statements only. The second highest ratio identified in Baluchistan Times newspapers headlines is expressive and emotions, feelings are associated with expressive speech acts. In the Baluchistan Time newspapers headlines expressive speech acts are indicated with the frequency of 6 and these speech acts are 15 in percentage. The moderate level of percentage is indicating that in the Baluchistan Times newspapers headlines, a little attention is given to the emotions and feelings. In the statements, three belongs to Shah Mehmood Qureshi out of six statements and he is expressing the cunning nature of India in front of world. At third number in Baluchistan Times newspapers headlines directives speech acts are observed. These are 5 in numbers and 12.5 in percentage representation. These are pronounced in the sense of obligations, command and directions. It can be concluded that editors of Baluchistan Times newspapers headlines are not frequently in a position to issue the orders and directions (ibid). In the commissive speech acts, it is expressed by the speaker that he has intentions for the fulfillments of actions in his future actions. These are detected with the frequency of 4 and percentage of 10 . These all three speech acts give the glimpses of commitment because performatives verbs are used in these headlines. All these three commissive speech acts are used with explicit verbs which advocate the politicians' pledges. The ratio of occurrence of declarative speech act in Baluchistan Times newspaper is extremely small. This can be judged from fact that it appears once I $n$ data presentation because in the news headlines it is seen that mostly the context does not permit to declaring the things instead of stating the news.

Analysis of Speech Acts in Baluchistan Times Newspapers Headlines

\begin{tabular}{|l|l|l|}
\hline Speech Act Types & Frequency & Percent \% \\
\hline $\begin{array}{l}\text { Representatives or } \\
\text { Assertives }\end{array}$ & 24 & $60 \%$ \\
\hline Expressive & 06 & $15 \%$ \\
\hline Directive & 05 & $12.5 \%$ \\
\hline Comissives & 04 & $10 \%$ \\
\hline Declarative & 01 & $2.5 \%$ \\
\hline
\end{tabular}

Table No. 2:

Analysis of Speech Acts in Baluchistan Time Newspapers Headlines 
Ramzan, Muhammad. et al. (2020) Comparative Pragmatic Study of Print media discourse in Balochistan newspapers headlines

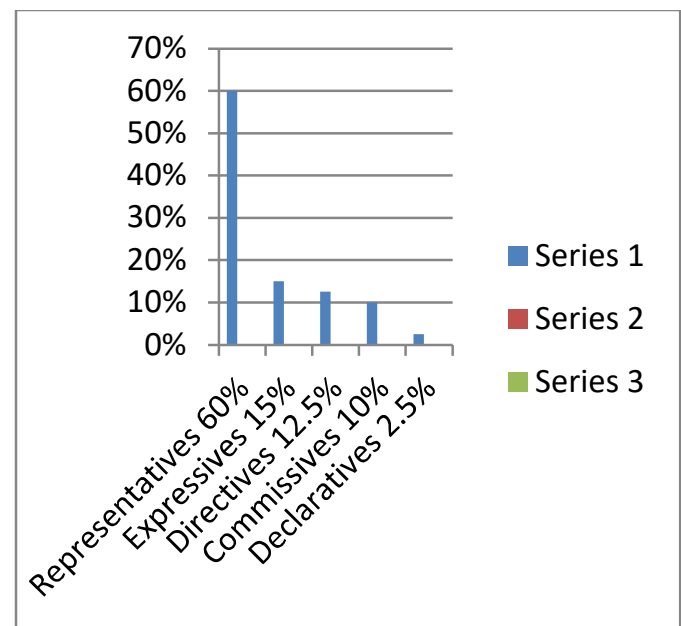

Figure No. 2:

After the completion of Talar (Noshkay) analysis in third newspapers headlines, the statistical analysis reveals that representative speech acts are again tend to reach at the highest percentage. The frequency of appearance in representative speech acts is recorded by percentage as $52.5 \%$ and amount as 21 . The study of newspapers currently indicates that the basic focus of the newspapers headlines is revolving around the current state of affairs. In the majority of headlines, verbs are being used as a tool for the description of illocutionary force whereas few headlines are also found as verb less. In the Talar (Noshkay) newspaper's headlines the second highest frequencies and percentages are found in expressive speech acts. Expressive speech acts are appearing in rate with percentage a $27.5 \%$ and frequency as 11 . In headlines major quantity of speech acts are observed as explicit and all expressive speech acts are describing the states of political disputes and deteriorated situation and issues of country and province. The expressive speech acts always describes the psychological attitude and state of mind of the speaker. The statements reveal that it is not so satisfactory. The commissive and directive are counted at third number simultaneously. In the analysis it was found that commissive and directive are 3 in frequency and these are 7.5 in percentage. In the analysis of whole sample of the study in Tular newspapers it is observed that the headlines are used mainly for the description and transmission of the news only because representatives are at highest level in this newspapers headline also.

Analysis of Speech Acts in Talar Newspapers Headlines

\begin{tabular}{|c|c|c|}
\hline Speech Act Type & Frequency & Percent \% \\
\hline $\begin{array}{l}\text { Representatives or } \\
\text { Assertives }\end{array}$ & 21 & $52.5 \%$ \\
\hline Expressives & 13 & $32.5 \%$ \\
\hline Directives & 03 & $7.5 \%$ \\
\hline Comissives & 03 & $7.5 \%$ \\
\hline Declaratives & - & - \\
\hline
\end{tabular}

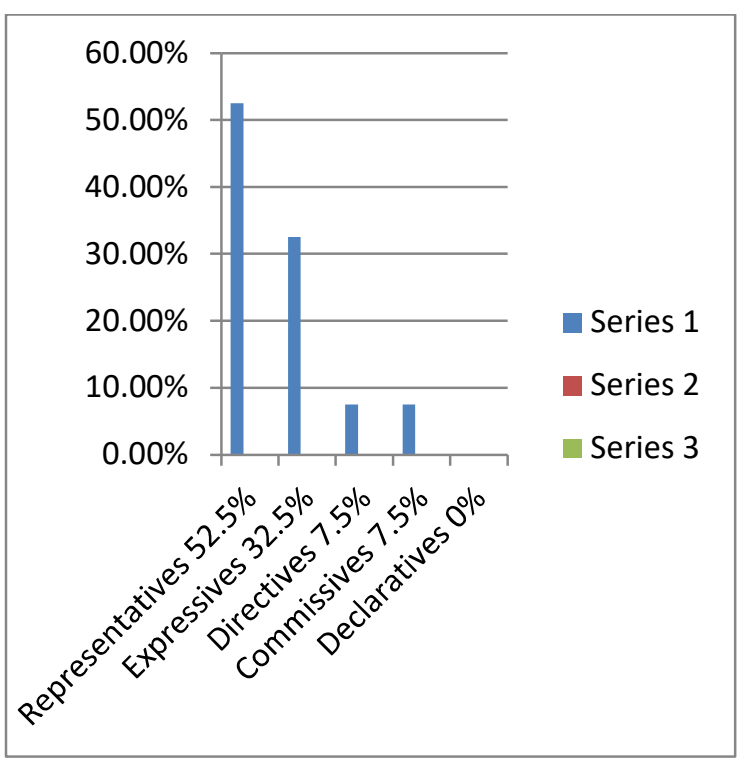

Figure No. 3:

As exemplified it the data while studying the performative strategy, it becomes clear that both explicit and implicit types of speech acts are used in all selected newspapers headlines. Moreover, it is inferred from the selected corpora that explicit speech acts figure more prominently then implicit speech acts in all the selected newspapers headlines.

\section{Findings}

The sample of the study has been analyzed pragmatically in the light of quantitative approach. The Pragmatic Study of Print Media Discourse in Baluchistan Newspapers Headlines was done in the light of Searle's taxonomy of speech acts from all the selected newspapers headlines e.g. Express (Quetta), Baluchistan Time and Talar (Noshkay). The results 
reveal that selected headlines show the illocutionary force that states the information to the readers mostly because assertive (Representatives) speech acts are used in the highest frequency and percentage. The major data of headlines in all selected newspapers is used explicitly. According to the previous sections, after carrying out the analysis and finding out the results, the researchers conclude the study with the following arguments.

As revealed in data representatives (Assertives) speech acts are used at highest frequency and percentage in all the selected newspapers headlines.

Declaratives speech acts are used at lowest level in Baluchistan Times newspapers headlines, and these are not employed in Express (Quetta) newspapers and Talar (Noshkay) newspapers headlines.

It is also revealed from the data analysis that aim of the speech acts is not threatening, advising, and frightening but they are just giving the description of news headlines as in the analysis representative speech acts are dominating in the data analysis.

The selected corpora from the headlines of newspapers lead to following observations.

The percentage of representatives (assertive) is equal $60 \%$ in the two selected headlines newspapers e.g. in Express (Quetta) and Baluchistan Times but in Talar (Noshkay) newspapers headlines it is noted as $52.5 \%$.

Directives speech acts are found to have fifth number in frequency and percentage in all selected headlines.

Certain differences in the data of research after analysis are also highlighted in the study along with similarities. It is indicated in the following points.

In Express newspapers Quetta headlines commissive speech acts stand at second highest level in frequency and percentage whereas in Baluchistan Times and Talar (Noshkay) newspapers headlines commissive speech acts are placed at number four but in both newspapers level of frequency and percentage is different.

Directives speech acts are employed at third number in Baluchistan Times and Talar newspapers headlines. Furthermore, directives speech acts stand equal in percentage and frequency in Express (Quetta) and Talar (Noshkay) newspapers headlines although directives speech acts are at fourth number in Express (Quetta) newspapers headlines but these speech acts are equal in percentage and frequency with commissive speech acts in Talar (Noshkay) newspapers headlines which are considered by the researchers at fourth number.

As revealed in data Expressive speech acts are employed at second number in Talar and Baluchistan Times newspapers headlines and these speech acts differ in frequency and percentage in these newspapers, where as in Express newspapers headlines Expressive speech acts are at third number in frequency and percentage.

The explicit and implicit speech acts are used in selected discourse but explicit speech acts stand at higher percentage and frequency of level as compared to the implicit speech acts in the all the selected newspapers headlines.

It can also be stated after the detailed analysis of data that employment of speech acts might be instrumental strategy for intended meanings. Furthermore, there can be the hidden ideological and manipulated stance in the use of speech acts.

\section{Conclusion:}

In present research it is attempted to evaluate the discourse in Baluchistan three newspapers headlines pragmatically. The ways of study are adopted in the light of Searle's taxonomy of speech acts and researchers have made following generalizations for the evaluation of conclusion in the study. The classifications of Searle's taxonomy of speech acts is applied on the sample of study in all selected newspapers headlines e.g. Express (Quetta), Baluchistan Time and Talar (Noshkay). It is concluded that all the newspapers headlines speech acts are employed in selected discourse but major focus is given to the transmission and broadcast of the news in all selected newspapers headlines because as it is revealed by the quantitative pragmatics analysis that representatives (assertives) speech acts are employed in highest frequencies and percentage in headlines e.g. Express (Quetta), Baluchistan Time and Talar newspapers as compared to the other categories. Moreover, it is also said by Hameed Ali and Hamood Ali (2018) that "assertives are used to give the truthful information to the reader". However, declaratives are figured in all the selected newspapers headlines with lowest frequency and percentage. The declaratives speech acts are used to describe the variations in the world. The sample of study is revealing that explicit and implicit speech acts are used in all selected newspapers e. g. Express (Quetta), Baluchistan Time and Talar newspapers and it is finally stated that 
explicit speech acts are occurring at highest level. After analyzing the headlines of selected newspapers in Baluchistan according to the speech acts taxonomy, researchers are assuming that there can be possibility to shape the belief of readers in headlines by the editors with the use of all types of speech acts. Subsequently, it is also highlighted that ideologies and power issues may be penetrated in the use of all types of speech acts in Baluchistan newspapers headlines along with broadcast of news headlines.

\section{References}

Abba, T.S. and Musa, N. (2015). Speech Act Analysis of Daily Trust and The Nation Newspapers Headline Reports on "Boko Haram" Attacks. Journal of Communication and Culture, 6 (1), 63-72.

Adegbola, O.F. (2019). Points of View and Modality in the Discourses of Homosexuality in Selected Nigerian Newspapers. International Journal of Linguistics, Literature and Translation, 2(4), 290-319.

Allan, K. (2001). Natural Language Semantics. Oxford: Blackwell.

Alrefaee, Y. et al. (2019) A Critical Discourse Analysis of the Selected Opposition and State Printed Media on the Representation of Southern Mobility in Yemen. International Journal of Linguistics, Literature and Translation, 2(2), 116-124

Austin, J.L. (1962). How to do things with words. Oxford: Oxford University Press.

Bach, K \& Harnish, R. k. (1979). Linguistic Communication and Speech Acts. Cambridge. MA: MIT Press.

Bach, K. (2004). Pragmatic and the philosophy of language. In Horn, L. R. and Ward, G. (eds) 463-87.

Chiluwa, I. (2007). News Headlines as Pragmatic Strategy in Nigerian Press Discourse. The International Journal of Language, Society and Culture, 27, 63-71.

Conboy, M. (2007). The Language of News. New York: Routledge.

Crystal, D. \& Davy, D. (1969). Investigating English Style. London: Longman.

Develotte, C., \& Rechniewski, E. (2001). Discourse Analysis of Newspaper Headlines: A methodological framework for research into national representations. Journal of French Media Studies, 1-16

Duanprakhon, P. (2012). "Critical Discourse Analysis of News Headlines: A Case of Youth Crime in Thailand.' Unpblished M. A. The sis National Institute of Development Administration.

Farrokhi, F., Ansarin, A. A., \& Ashrafi, S. (2019). The Conceptual Metaphors of Building and Construction in Newspaper and Research Article. International Journal of Linguistics, Literature and Translation, 2(4), 290-328.

Huang, Y. (2007). Pragmatics. Beijing: Oxford University Press.

Hameed Ali and Hamood Ali's (2018). A Pragmatic Study of CNN and BBC News Headlines Covering the Syrian Conflict analyzing the speech act analysis. Advances in Language and Literary Studies.9(3):43-51

Ismajli, F. (2020). Transforming News Journalism from Newspapers into Online Media in Kosovo. International Journal of Linguistics, Literature and Translation, 3(1), 214-225

Ismail, H. M. (2016). Pragmatic and Semantic Potential of Newspaper Headlines. US-China Foreign Language. David Publishing. 14(11), 753-762.

Jabbar W.K. and JasimT. J. (2020). A Pragmatic Study of Newspapers Headlines in Media Discourse: Iraq as a Case Study. International Journal of Linguistics, Literature and Translation 3(3) 48-59.

Lakoff, G. (1972). Hedges: A Study in Meaning Criteria and the Logic of Fuzzi Concepts. Papers from the Regional Meeting of Chicago Linguistics Society, 1983-228.

Leech, G. N. (1983). Principles of Pragmatics. London: Longman. [18] Mey, J. (2001). Pragmatics: an Introduction. 2nd ed. Oxford: Blackwell. IJLLT 3(3):48-59

Mohamed, E. A. A. A. (2020). Newspapers as Carriers of New Terms Namely (Neologism) and Their role in Enhancing Students' Vocabulary: Guardian Newspaper as a Model. International Journal of Linguistics, Literature and Translation, 3(2), 180-196.

Monsefi, R. and Mahadi, T. (2017). The Rhetoric of Persian News Headlines: A Case Study of Euronews. International Journal of Applied Linguistics and English Literature, 6(2), 3645. 
Ramzan, Muhammad. et al. (2020) Comparative Pragmatic Study of Print media discourse in Balochistan newspapers headlines

Nendauni, L., \& Sadiki, M. F. (2019). Persuasion in the Mirror Newspaper: A Linguistic Approach to Vuwani Demarcation Discourses. International Journal of Linguistics, Literature and Translation, 2(5), 290-364.

Reah, D. (2002). The Language of Newspaper. 2nd Edition London: Rutledge.

Reah, D. (1998). The Language of Newspaper. London: Rutledge.

Ross, J. R. (1970). On declarative sentences. In Jacobs. R. and Rosenbaum, P. S. (eds). Readings in English Transformational Grammar. Waltham Ginn, 222-72.

Roya, M. \& Mahadi, T.(2017). The Rhetoric of Persian News Headlines:A Case Study of Eurinews, International Journal of Applied Linguistics and English Literature,6(2) March .pp.36-45

Rustam, R. (2013). Pragmatic Analysis of CNN Headlines Representing Pakistan. Unpublished Ph.D. Dissertation, University of Azad Jammu and Kashmir, Muzaffarabad, Pakistan.

Sadock, J. M. (1974). Toward a Linguistic Theory of Speech Acts. New York: Academic Press.

Searle, J. R. (1969). Speech Acts: An Essay in the Philosophy of Language. Cambridge: Cambridge University Press.

Searle, J. R. (1975). Taxonomy of Speech Acts. In Gunderson, K. (ed). Minnesota Studies in the Philosophy of Science 9: Language, Mind and Knowledge, 344-69.

Searle, J. R. (1979). A Taxonomy of Illocutionary Acts, in Searle J. R. (ed.) Expression and Meaning: Studies in the Theory of Speech Acts, Cambridge: Cambridge University Press pp. 1-29 (originally published in 1975).

Siposova, A. (2011). Headlines and Subheadlines: Tense, Modality and Register Based on Discourse Analysis of the British Tobloid the Sun. Unpublished Master's Thesis. Dissertation, Masaryk University, Berno, Czech Republic.

Taiwo,R. (2007). Language, Ideology and Power Relations in Nigerian Newspaper Headlines. Nebula, 4(1). 218- 245

Tuchman, G. (1978). Making News a Study of the Construction of Reality. NY: Free Press.
Ungerer, F. (Ed.). (2000). English Media Texts-Past and Present Language and Textual Structure. Philadelphia PA: John Benjamin's.

Van Dijk, T. A. (1988). News as Discourse. Hillsdale, NJ: Lawrence Erlbaum. [35] Van Dijk, T. A. (1991). Racism and the press. London: Routledge.

Van Dijk, T. A.(1997). Text and Context. Explorations in the Semantics and Pragmatics of Discourse. London. Longman.

\section{APPENDIX}

\section{Appendix (A): Headlines of Express (Quetta Newspapers) Baluchistan}

\begin{tabular}{|c|c|c|c|}
\hline $\begin{array}{l}\text { S. } \\
\text { No. }\end{array}$ & Headlines & $\begin{array}{c}\text { Classificat } \\
\text { ion }\end{array}$ & Date \\
\hline 1 & 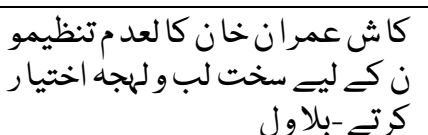 & Expressive & $\begin{array}{l}09-03- \\
19\end{array}$ \\
\hline 2 & 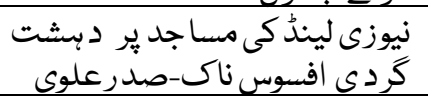 & Expressive & $\begin{array}{l}16-03- \\
19\end{array}$ \\
\hline 3 & 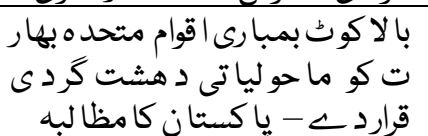 & Directive & $\begin{array}{l}16-03- \\
19\end{array}$ \\
\hline 4 & 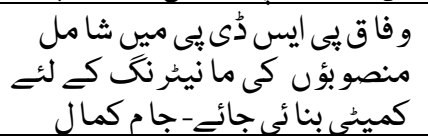 & Directive & $\begin{array}{l}16-03- \\
19\end{array}$ \\
\hline 5 & 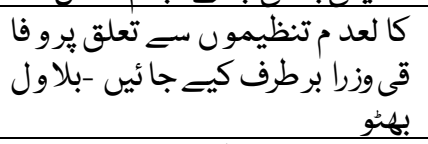 & Directive & $\begin{array}{l}14-03- \\
19\end{array}$ \\
\hline 6 & 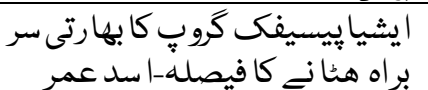 & $\begin{array}{l}\text { Representa } \\
\text { tive }\end{array}$ & $\begin{array}{l}10-03- \\
19\end{array}$ \\
\hline 7 & 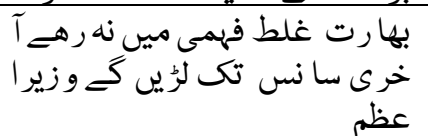 & $\begin{array}{l}\text { Commissiv } \\
\text { e }\end{array}$ & $\begin{array}{l}09-03- \\
20\end{array}$ \\
\hline 8 & 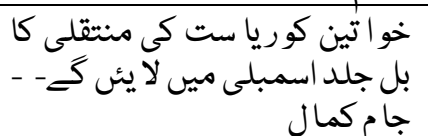 & Commissiv & $\begin{array}{l}09-03- \\
20\end{array}$ \\
\hline 9 & 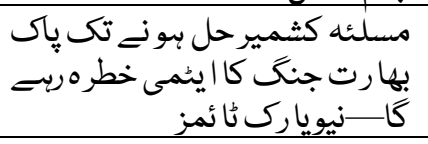 & $\begin{array}{l}\text { Representa } \\
\text { tive }\end{array}$ & $\begin{array}{l}09-03- \\
20\end{array}$ \\
\hline 10 & 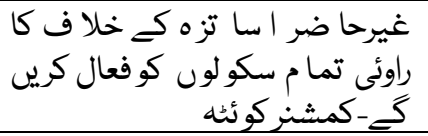 & $\begin{array}{l}\text { Commissiv } \\
\text { e }\end{array}$ & $\begin{array}{l}09-03- \\
20\end{array}$ \\
\hline 11 & 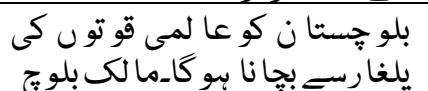 & $\begin{array}{l}\text { Commissiv } \\
\text { e }\end{array}$ & $\begin{array}{l}10-03- \\
20\end{array}$ \\
\hline
\end{tabular}


Ramzan, Muhammad. et al. (2020) Comparative Pragmatic Study of Print media discourse in Balochistan newspapers headlines

\begin{tabular}{|c|c|c|c|}
\hline 12 & 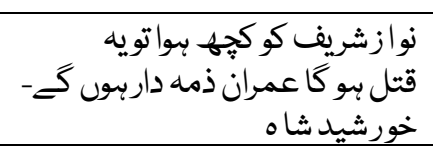 & Expressive & $\begin{array}{l}11-03- \\
20\end{array}$ \\
\hline 13 & 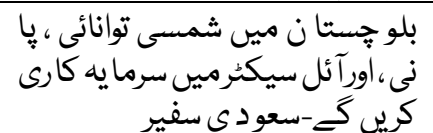 & $\begin{array}{l}\text { Commissiv } \\
\text { e }\end{array}$ & $\begin{array}{l}12-03- \\
20\end{array}$ \\
\hline 14 & 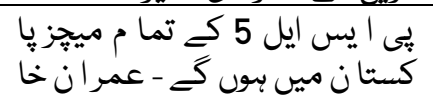 & $\begin{array}{l}\text { Representa } \\
\text { tive }\end{array}$ & $\begin{array}{l}15-03- \\
20\end{array}$ \\
\hline 15 & 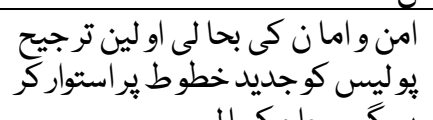 & $\begin{array}{l}\text { Commissiv } \\
\text { e }\end{array}$ & $\begin{array}{l}15-03- \\
20\end{array}$ \\
\hline 16 & 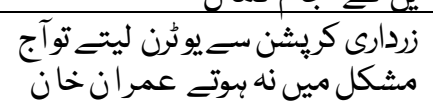 & $\begin{array}{l}\text { Representa } \\
\text { tive }\end{array}$ & $\begin{array}{l}09-03- \\
19\end{array}$ \\
\hline 17 & 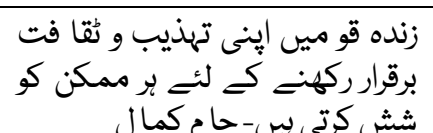 & $\begin{array}{l}\text { Representa } \\
\text { tive }\end{array}$ & $\begin{array}{l}09-03- \\
19\end{array}$ \\
\hline 18 & 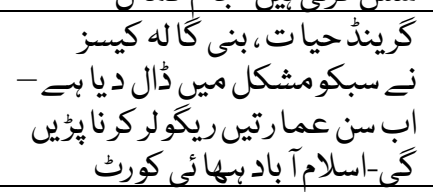 & $\begin{array}{l}\text { Commissiv } \\
\text { e }\end{array}$ & $\begin{array}{l}09-03- \\
19\end{array}$ \\
\hline 19 & 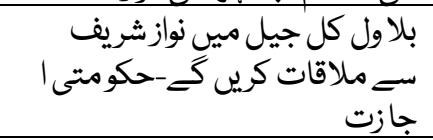 & $\begin{array}{l}\text { Representa } \\
\text { tive }\end{array}$ & $\begin{array}{l}09-03- \\
19\end{array}$ \\
\hline 20 & 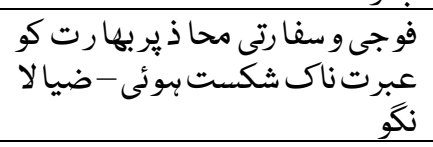 & $\begin{array}{l}\text { Representa } \\
\text { tive }\end{array}$ & $\begin{array}{l}09-03- \\
19\end{array}$ \\
\hline 21 & 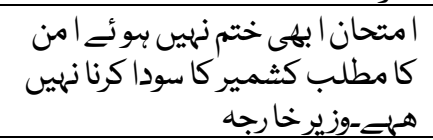 & Expressive & $\begin{array}{l}11-03- \\
19\end{array}$ \\
\hline 22 & 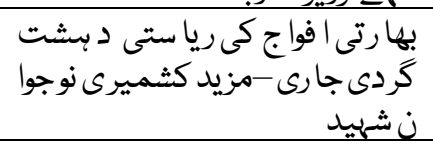 & $\begin{array}{l}\text { Representa } \\
\text { tive }\end{array}$ & $\begin{array}{l}11-03- \\
19\end{array}$ \\
\hline 23 & 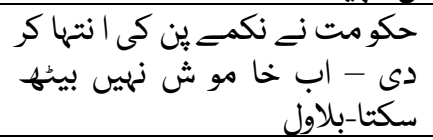 & Expressive & $\begin{array}{l}11-03- \\
19\end{array}$ \\
\hline 24 & 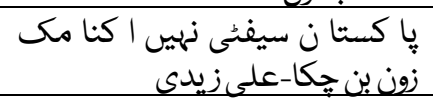 & $\begin{array}{l}\begin{array}{l}\text { Representa } \\
\text { tive }\end{array} \\
\end{array}$ & $\begin{array}{l}11-03- \\
19\end{array}$ \\
\hline 25 & 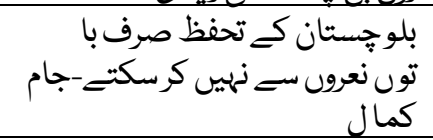 & Expressive & $\begin{array}{l}11-03- \\
19\end{array}$ \\
\hline 26 & 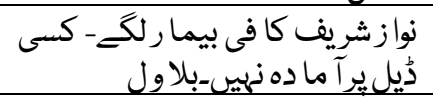 & \begin{tabular}{|l|} 
Representa \\
tive
\end{tabular} & \begin{tabular}{|l|}
$12-03-$ \\
19 \\
\end{tabular} \\
\hline 27 & 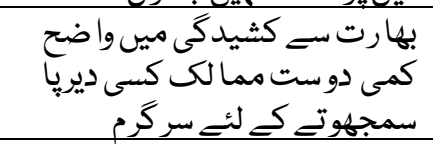 & \begin{tabular}{|l|} 
Representa \\
tive
\end{tabular} & $\begin{array}{l}12-03- \\
19\end{array}$ \\
\hline 28 & 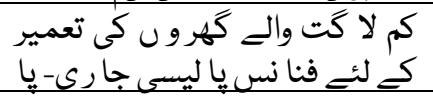 & $\begin{array}{l}\text { Representa } \\
\text { tive }\end{array}$ & $\begin{array}{l}12-03- \\
19\end{array}$ \\
\hline
\end{tabular}

\begin{tabular}{|c|c|c|c|}
\hline & 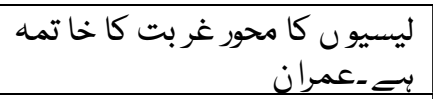 & & \\
\hline 29 & 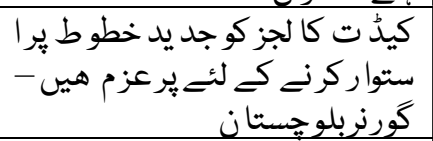 & $\begin{array}{l}\text { Representa } \\
\text { tive }\end{array}$ & $\begin{array}{l}12-03- \\
19\end{array}$ \\
\hline 30 & 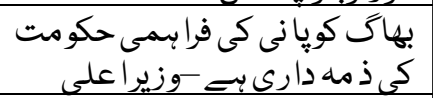 & $\begin{array}{l}\begin{array}{l}\text { Representa } \\
\text { tive }\end{array} \\
\end{array}$ & $19^{12-03}$ \\
\hline 31 & 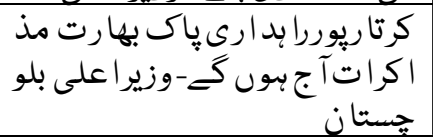 & $\begin{array}{l}\text { Representa } \\
\text { tive }\end{array}$ & $\begin{array}{l}14-03- \\
19\end{array}$ \\
\hline 32 & 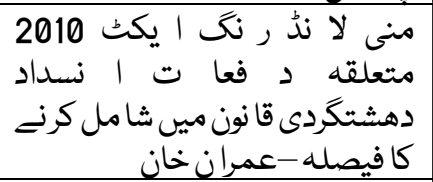 & $\begin{array}{l}\text { Representa } \\
\text { tive }\end{array}$ & $\begin{array}{l}14-03- \\
19\end{array}$ \\
\hline 33 & 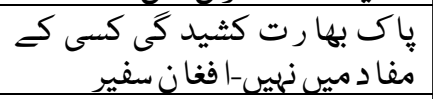 & $\begin{array}{l}\text { Representa } \\
\text { tive }\end{array}$ & $\begin{array}{l}14-03- \\
19\end{array}$ \\
\hline 34 & 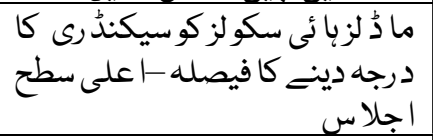 & $\begin{array}{l}\text { Representa } \\
\text { tive }\end{array}$ & $\begin{array}{l}14-03- \\
19\end{array}$ \\
\hline 35 & 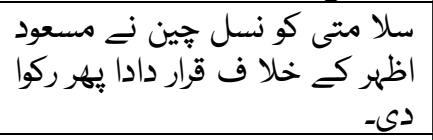 & $\begin{array}{l}\text { Representa } \\
\text { tive }\end{array}$ & $\begin{array}{l}14-03- \\
19\end{array}$ \\
\hline 36 & 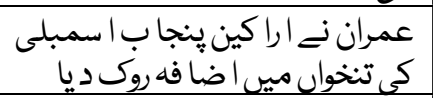 & $\begin{array}{l}\text { Representa } \\
\text { tive }\end{array}$ & \begin{tabular}{|l|}
$15-03-$ \\
19 \\
\end{tabular} \\
\hline 37 & 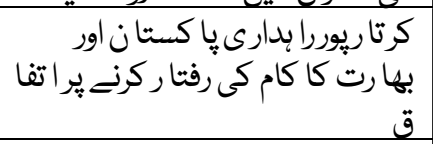 & $\begin{array}{l}\text { Representa } \\
\text { tive }\end{array}$ & $\begin{array}{l}15-03- \\
19\end{array}$ \\
\hline 38 & 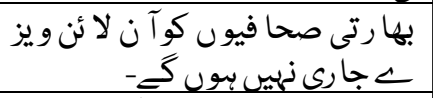 & \begin{tabular}{|l}
$\begin{array}{l}\text { Representa } \\
\text { tive }\end{array}$ \\
\end{tabular} & \begin{tabular}{|l|}
$15-03-$ \\
19 \\
\end{tabular} \\
\hline 39 & 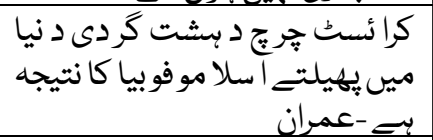 & $\begin{array}{l}\text { Representa } \\
\text { tive }\end{array}$ & $\begin{array}{l}16-03- \\
19\end{array}$ \\
\hline 40 & نيو زي ليندُ مسيا جد ميس فائرنَ & $\begin{array}{l}\text { Representa } \\
\text { tive }\end{array}$ & $\begin{array}{l}16-03- \\
19\end{array}$ \\
\hline
\end{tabular}

Appendix (B): Headlines of Baluchistan Time (Quetta Newspapers) Baluchistan

\begin{tabular}{|c|l|l|l|}
\hline $\begin{array}{c}\text { S. } \\
\text { No. }\end{array}$ & \multicolumn{1}{|c|}{ Headlines } & Classification & Date \\
\hline 1 & $\begin{array}{l}\text { US Newspaper names } \\
\text { PM Imran Khan in the } \\
\text { list for peace prize. }\end{array}$ & Declarative & $\begin{array}{l}11-03- \\
2019\end{array}$ \\
\hline 2 & $\begin{array}{l}\text { Neighbor blame } \\
\text { Pakistan without any } \\
\text { evidence laments } \\
\text { Qureshi Expressive }\end{array}$ & $\begin{array}{l}11-03- \\
2019\end{array}$ \\
\hline 3 & $\begin{array}{l}\text { India wants to isolate } \\
\text { Pakistan }\end{array}$ & Expressive & $\begin{array}{l}11-03- \\
2019\end{array}$ \\
\hline
\end{tabular}




\begin{tabular}{|c|c|c|c|}
\hline & $\begin{array}{l}\text { diplomatically. } \\
\text { Qureshi }\end{array}$ & & \\
\hline 4 & $\begin{array}{l}\text { PM Khan lauds SBP } \\
\text { for low cost housing } \\
\text { incentives. }\end{array}$ & Expressive & $\begin{array}{l}12-03- \\
2019\end{array}$ \\
\hline 5 & $\begin{array}{ll}\text { Indian intrusion was } \\
\text { violation of } \\
\text { charter. Qureshi }\end{array}$ & Expressive & $\begin{array}{l}12-03- \\
2019\end{array}$ \\
\hline 6 & $\begin{array}{l}\text { Accused are all } \\
\text { acquitted due to false } \\
\text { testimony. }\end{array}$ & Expressive & $\begin{array}{l}13-03- \\
2019\end{array}$ \\
\hline 7 & $\begin{array}{l}\text { Germany appreciates } \\
\text { Pakistan efforts for } \\
\text { restoring peace in } \\
\text { Afghanistan. }\end{array}$ & Representative & $\begin{array}{l}13-03- \\
2019\end{array}$ \\
\hline 8 & $\begin{array}{l}\text { President urges for } \\
\text { portraying positive } \\
\text { aspects of Pakistan } \\
\text { society through fine } \\
\text { arts. }\end{array}$ & Directive & $\begin{array}{l}14-03- \\
2019\end{array}$ \\
\hline 9 & $\begin{array}{l}\text { Asad Umer asks } \\
\text { FATF president to } \\
\text { remove India as a co- } \\
\text { chair to ensure } \\
\text { impartial assessment. }\end{array}$ & Directive & $\begin{array}{l}10-03- \\
2019\end{array}$ \\
\hline 10 & $\begin{array}{l}\text { Germany urges Pak } \\
\text { India to resolve issues } \\
\text { through dialogues. }\end{array}$ & Directive & $\begin{array}{l}13-03- \\
2019\end{array}$ \\
\hline 11 & $\begin{array}{l}\text { President calls for } \\
\text { strengthening } \\
\text { transport } \\
\text { communication } \\
\text { infrastructure in ECO } \\
\text { region. }\end{array}$ & Directive & $\begin{array}{l}15-03- \\
2019\end{array}$ \\
\hline 12 & $\begin{array}{lr}\text { Nawaz } & \text { Shareef } \\
\text { advises } & \text { PML-N } \\
\text { workers to stay calm. }\end{array}$ & Directive & $\begin{array}{l}16-03- \\
2019\end{array}$ \\
\hline 13 & $\begin{array}{l}\text { Model courts to be } \\
\text { established at district } \\
\text { level across the } \\
\text { country. CJP }\end{array}$ & Commissive & $\begin{array}{l}12-03- \\
2019\end{array}$ \\
\hline 14 & $\begin{array}{lr}\text { Zero } & \text { tolerance } \\
\text { towards } & \text { terrorism, } \\
\text { decides } & \text { apex } \\
\text { committee. } & \\
\end{array}$ & Commissive & $\begin{array}{l}13-03- \\
2019\end{array}$ \\
\hline 15 & $\begin{array}{l}\text { PM promises towards } \\
\text { development } \\
\text { opportunities in tribal } \\
\text { districts. }\end{array}$ & Commissive & $\begin{array}{l}16-03- \\
2019\end{array}$ \\
\hline 16 & $\begin{array}{l}\text { Voices in India are } \\
\text { saying New Delhi has } \\
\text { lost Kashmir. Shah } \\
\text { Mehmood }\end{array}$ & $\begin{array}{l}\text { Representa- } \\
\text { tive }\end{array}$ & $\begin{array}{l}10-03- \\
19\end{array}$ \\
\hline
\end{tabular}

\begin{tabular}{|c|c|c|c|}
\hline 17 & $\begin{array}{l}\text { Nawaz never insisted } \\
\text { on going abroad for } \\
\text { treatment. }\end{array}$ & $\begin{array}{l}\text { Represent- } \\
\text { ative }\end{array}$ & $\begin{array}{l}10-03- \\
19\end{array}$ \\
\hline 18 & $\begin{array}{l}\text { NAB summons } \\
\text { Bilawal, Zardari, } \\
\text { Talpur in fake bank } \\
\text { account case. }\end{array}$ & $\begin{array}{l}\text { Represent- } \\
\text { ative }\end{array}$ & $\begin{array}{l}10-03- \\
19\end{array}$ \\
\hline 19 & $\begin{array}{l}\text { PDM issues high alert } \\
\text { as more torrential } \\
\text { rains expected in } \\
\text { Baluchistan. }\end{array}$ & Representative & $\begin{array}{l}10-03- \\
19\end{array}$ \\
\hline 20 & $\begin{array}{ll}\text { Baluchistan's } & \text { rights } \\
\text { need practical } & \text { steps. } \\
\text { CM Kamlal } & \end{array}$ & Commissive & $\begin{array}{l}11-03- \\
19\end{array}$ \\
\hline 21 & $\begin{array}{l}\text { Modi put regional } \\
\text { peace at risk for } \\
\text { electoral gains. Asad } \\
\text { Qaisar }\end{array}$ & Representative & $\begin{array}{l}11-03- \\
19\end{array}$ \\
\hline 22 & $\begin{array}{l}\text { Baluchistan assembly } \\
\text { aggressively } \\
\text { legislating to bring } \\
\text { reforms in various } \\
\text { sectors. Baluchistan } \\
\text { Information Minister }\end{array}$ & Representative & $\begin{array}{l}11-03- \\
19\end{array}$ \\
\hline 23 & $\begin{array}{l}\text { Government } \\
\text { departments on high } \\
\text { alerts following } \\
\text { torrential rains in } \\
\text { Baluchistan }\end{array}$ & Representative & $\begin{array}{l}11-03- \\
19\end{array}$ \\
\hline 24 & $\begin{array}{l}\text { India diverts water } \\
\text { from three eastern } \\
\text { rivers following into } \\
\text { Pakistan. }\end{array}$ & Representative & $\begin{array}{l}12-03- \\
19\end{array}$ \\
\hline 25 & $\begin{array}{l}\text { Pakistan has taken } \\
\text { steps to address FATF } \\
\text { reservations. Umar }\end{array}$ & Representative & $\begin{array}{l}12-03- \\
19\end{array}$ \\
\hline 26 & $\begin{array}{l}\text { Pakistan } \\
\text { testifiers } \\
\text { range smart } \\
\text { adds weaponded } \\
\text { capability. }\end{array}$ & Representative & $\begin{array}{l}13-03- \\
19\end{array}$ \\
\hline 27 & $\begin{array}{l}\text { Two terrorists, three } \\
\text { abettors nabbed in } \\
\text { Mansehra. ISPR }\end{array}$ & Representative & $\begin{array}{l}13-03- \\
19\end{array}$ \\
\hline 28 & $\begin{array}{l}\text { India refuses visas to } \\
\text { Pakistani journalists. }\end{array}$ & Representative & $\begin{array}{l}13-03- \\
19\end{array}$ \\
\hline 29 & $\begin{array}{l}\text { MP seeks new taxes } \\
\text { machinery to go after } \\
\text { evaders. }\end{array}$ & Representative & $\begin{array}{l}14-03- \\
19\end{array}$ \\
\hline 30 & $\begin{array}{l}\text { CM Kamal addresses } \\
\text { participants of } \\
\text { military staff courses. }\end{array}$ & Representative & $\begin{array}{l}14-03- \\
19\end{array}$ \\
\hline 31 & $\begin{array}{l}\text { UK appreciates } \\
\text { Pakistan positive role } \\
\text { for regional peace }\end{array}$ & Expressive & $\begin{array}{l}14-03- \\
19\end{array}$ \\
\hline
\end{tabular}


Ramzan, Muhammad. et al. (2020) Comparative Pragmatic Study of Print media discourse in Balochistan newspapers headlines

\begin{tabular}{|c|l|l|l|}
\hline 32 & $\begin{array}{l}\text { Revitalization of } \\
\text { National economy } \\
\text { Govt's top priority }\end{array}$ & Representative & $14-03-$ \\
\hline 33 & $\begin{array}{l}\text { PM Imran Khan bars } \\
\text { Punjab governor from } \\
\text { singing MPA,s salary } \\
\text { raise summary. }\end{array}$ & Representative & $15-03-$ \\
\hline 34 & $\begin{array}{l}\text { PM inaugurates } \\
\text { online visa system to } \\
\text { attract investment into } \\
\text { Pakistan. }\end{array}$ & Representative & 19 \\
\hline 35 & $\begin{array}{l}\text { Accountability court } \\
\text { allows police to } \\
\text { interrogate Nawaz in } \\
\text { model town case. }\end{array}$ & Representative & 19 \\
\hline 36 & $\begin{array}{l}\text { Pakistan playing vital } \\
\text { role in fighting } \\
\text { terrorism. in terror }\end{array}$ & Representative & 19 \\
\hline 37 & $\begin{array}{l}49 \text { dead in ter-03- } \\
\text { attacks on two New } \\
\text { Zealand mosques. }\end{array}$ & Representative & 19 \\
\hline 38 & $\begin{array}{l}\text { Pakistan lodges } \\
\text { complaint in UN } \\
\text { against India over eco } \\
\text { terrorism. }\end{array}$ & Representative & 19 \\
\hline 39 & $\begin{array}{l}\text { Pakistan opens up for } \\
\text { economic } \\
\text { development trade } \\
\text { connectivity. Asad } \\
\text { Umar }\end{array}$ & Representative & $16-03-$ \\
\hline 40 & $\begin{array}{l}\text { Qureshi expected to } \\
\text { travel Beijing for } \\
\text { Pak- China strategic } \\
\text { consultation }\end{array}$ & Representative & 19 \\
\hline
\end{tabular}

\begin{tabular}{|c|c|c|c|}
\hline 3 & 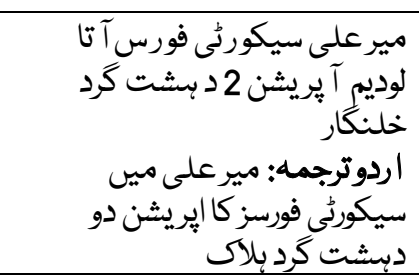 & $\begin{array}{l}\text { Represent } \\
\text { ative }\end{array}$ & $\begin{array}{l}05-10- \\
20\end{array}$ \\
\hline 4 & 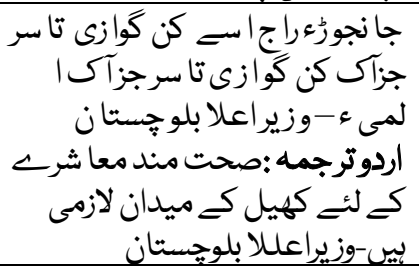 & $\begin{array}{l}\text { Represent } \\
\text { ative }\end{array}$ & $\begin{array}{l}05-10- \\
20\end{array}$ \\
\hline 5 & 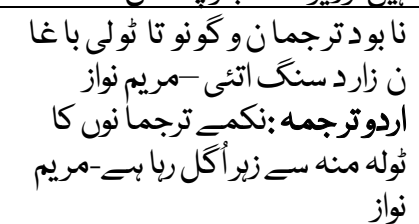 & $\begin{array}{l}\text { Expressiv } \\
\text { e }\end{array}$ & $\begin{array}{l}05-10- \\
20\end{array}$ \\
\hline 6 & 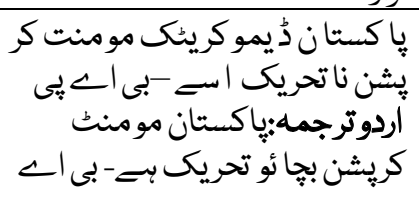 & $\begin{array}{l}\text { Represent } \\
\text { ative }\end{array}$ & $\begin{array}{l}05-10- \\
20\end{array}$ \\
\hline 7 & 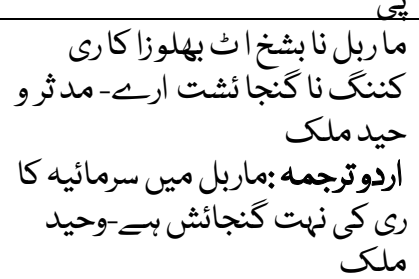 & $\begin{array}{l}\text { Represent } \\
\text { ative }\end{array}$ & $\begin{array}{l}05-10- \\
20\end{array}$ \\
\hline 8 & 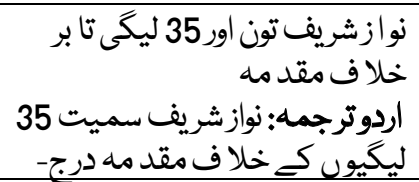 & $\begin{array}{l}\text { Represent } \\
\text { ative }\end{array}$ & $\begin{array}{l}06-10- \\
20\end{array}$ \\
\hline 9 & 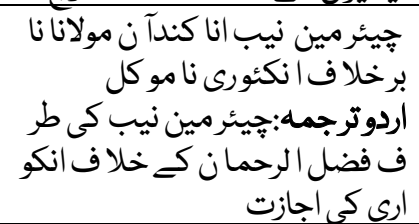 & $\begin{array}{l}\text { Represent } \\
\text { ative }\end{array}$ & $\begin{array}{l}06-10- \\
20\end{array}$ \\
\hline 10 & 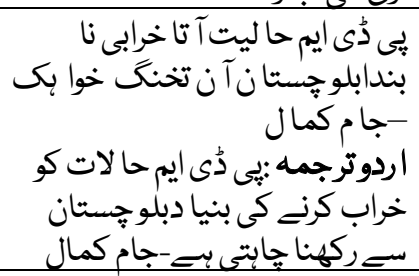 & $\begin{array}{l}\text { Expressiv } \\
\mathrm{e}\end{array}$ & $\begin{array}{l}06-10- \\
20\end{array}$ \\
\hline 11 & 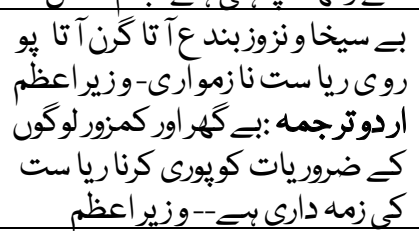 & $\begin{array}{l}\text { Represent } \\
\text { ative }\end{array}$ & $\begin{array}{l}06-10- \\
20\end{array}$ \\
\hline 12 & 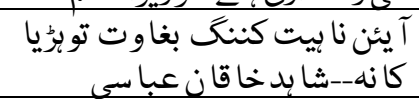 & $\begin{array}{l}\text { Expressiv } \\
\mathrm{e}\end{array}$ & $\begin{array}{l}06-10- \\
20\end{array}$ \\
\hline
\end{tabular}

Appendix (C): Headlines of تلا ر (نو شكح) (Quetta Newspapers) Baluchistan

\begin{tabular}{|c|c|c|c|}
\hline $\begin{array}{l}\text { S. } \\
\text { No. }\end{array}$ & Headlines & $\begin{array}{l}\text { Classifica } \\
\text { tion }\end{array}$ & Date \\
\hline 1 & 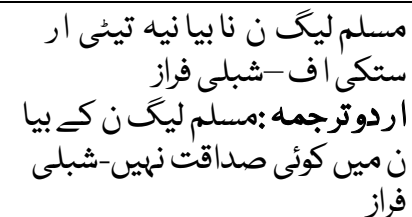 & $\begin{array}{l}\text { Expressiv } \\
\text { e }\end{array}$ & $\begin{array}{l}05-10- \\
20\end{array}$ \\
\hline 2 & 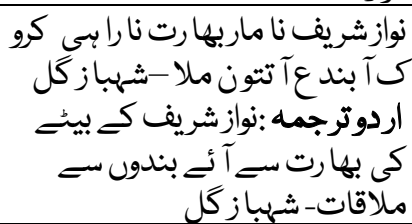 & $\begin{array}{l}\text { Represent } \\
\text { ative }\end{array}$ & $\begin{array}{l}05-10- \\
20\end{array}$ \\
\hline
\end{tabular}




\begin{tabular}{|c|c|c|c|}
\hline & 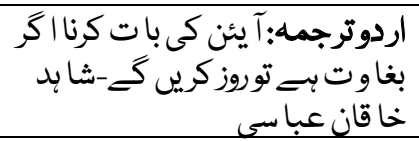 & & \\
\hline 13 & 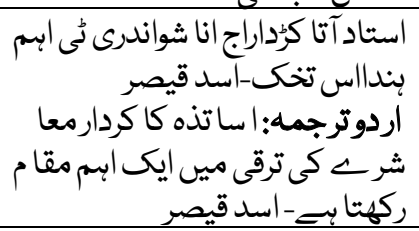 & $\begin{array}{l}\text { Represent } \\
\text { ative }\end{array}$ & $\begin{array}{l}06-10- \\
20\end{array}$ \\
\hline 14 & 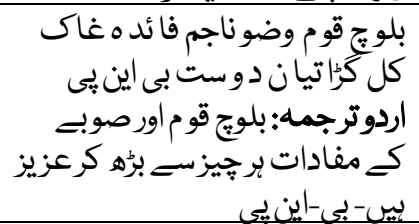 & $\begin{array}{l}\text { Expressiv } \\
\mathrm{e}\end{array}$ & $\begin{array}{l}06-10- \\
20\end{array}$ \\
\hline 15 & 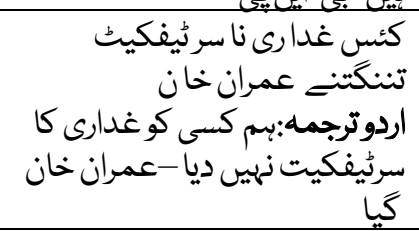 & $\begin{array}{l}\text { Represent } \\
\text { ative }\end{array}$ & $\begin{array}{l}07-10- \\
20\end{array}$ \\
\hline 16 & 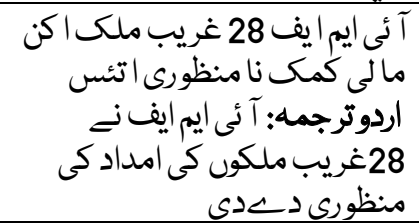 & $\begin{array}{l}\text { Represent } \\
\text { ative }\end{array}$ & $\begin{array}{l}07-10- \\
20\end{array}$ \\
\hline 17 & 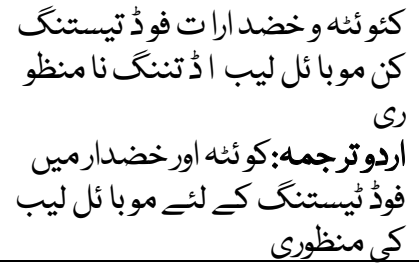 & $\begin{array}{l}\text { Represent } \\
\text { ative }\end{array}$ & $\begin{array}{l}07-10- \\
20\end{array}$ \\
\hline 18 & 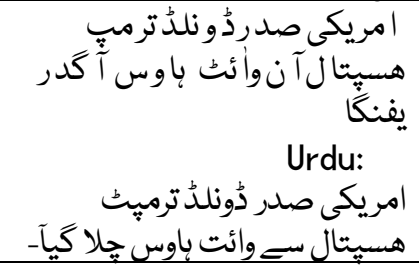 & $\begin{array}{l}\text { Represent } \\
\text { ative }\end{array}$ & $\begin{array}{l}07-10- \\
20\end{array}$ \\
\hline 19 & 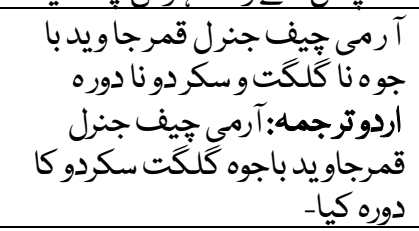 & $\begin{array}{l}\text { Represent } \\
\text { ative }\end{array}$ & $\begin{array}{l}07-10- \\
20\end{array}$ \\
\hline 20 & 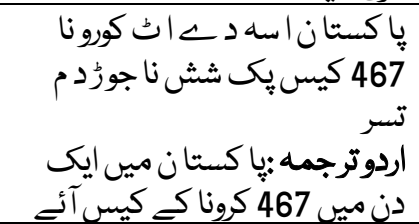 & $\begin{array}{l}\text { Represent } \\
\text { ative }\end{array}$ & $\begin{array}{l}07-10- \\
20\end{array}$ \\
\hline 21 & 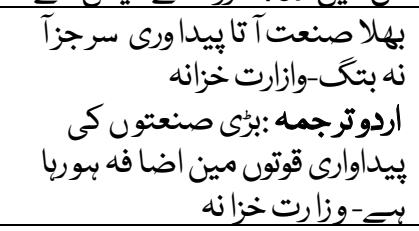 & $\begin{array}{l}\text { Represent } \\
\text { ative }\end{array}$ & $\begin{array}{l}07-10- \\
20\end{array}$ \\
\hline
\end{tabular}

\begin{tabular}{|c|c|c|c|}
\hline 22 & 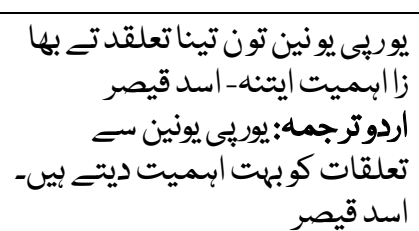 & $\begin{array}{l}\text { Represent } \\
\text { ative }\end{array}$ & $\begin{array}{l}07-10- \\
20\end{array}$ \\
\hline 23 & 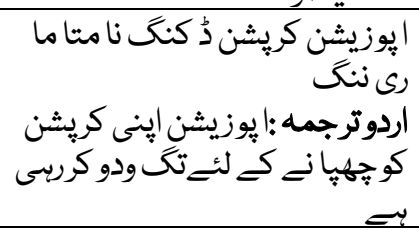 & $\begin{array}{l}\text { Expressiv } \\
\mathrm{e}\end{array}$ & $\begin{array}{l}08-10- \\
20\end{array}$ \\
\hline 24 & 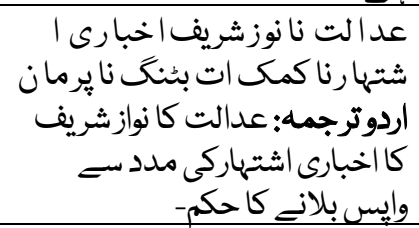 & $\begin{array}{l}\text { Represent } \\
\text { ative }\end{array}$ & $\begin{array}{l}08-10- \\
20\end{array}$ \\
\hline 25 & 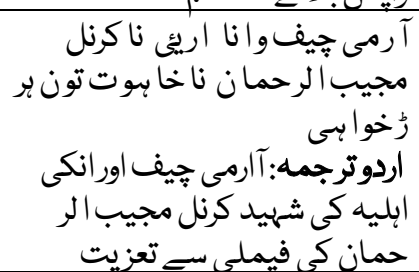 & $\begin{array}{l}\text { Represent } \\
\text { ative }\end{array}$ & $\begin{array}{l}08-10- \\
20\end{array}$ \\
\hline 26 & 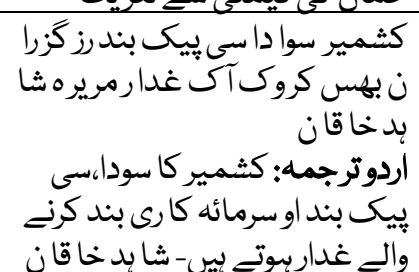 & $\begin{array}{l}\text { Expressiv } \\
\mathrm{e}\end{array}$ & $\begin{array}{l}08-10- \\
20\end{array}$ \\
\hline 27 & 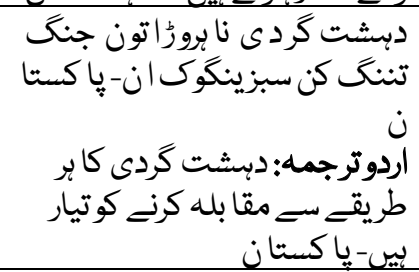 & $\begin{array}{l}\text { Expressiv } \\
\mathrm{e}\end{array}$ & $\begin{array}{l}08-10- \\
20\end{array}$ \\
\hline 28 & 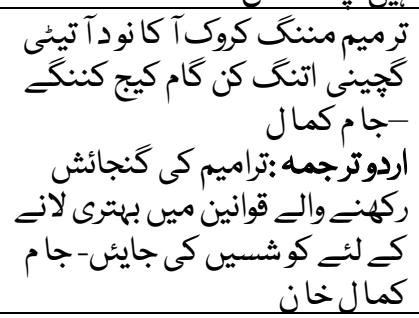 & Directive & $\begin{array}{l}08-10- \\
20\end{array}$ \\
\hline 29 & 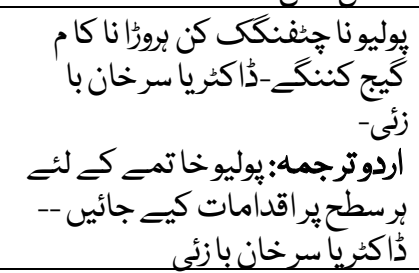 & Directive & $\begin{array}{l}08-10- \\
20\end{array}$ \\
\hline 30 & 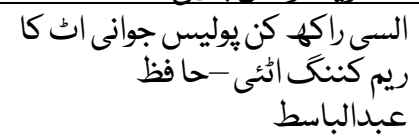 & $\begin{array}{l}\text { Represent } \\
\text { ative }\end{array}$ & $\begin{array}{l}08-10- \\
20\end{array}$ \\
\hline
\end{tabular}


Ramzan, Muhammad. et al. (2020) Comparative Pragmatic Study of Print media discourse in Balochistan newspapers headlines

\begin{tabular}{|c|c|c|c|}
\hline & 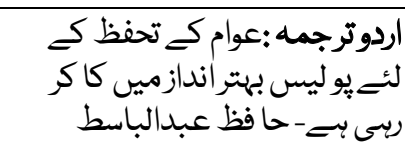 & & \\
\hline 31 & 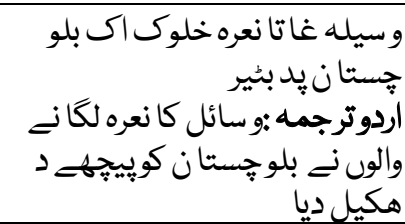 & $\begin{array}{l}\text { Expressiv } \\
\text { e }\end{array}$ & $\begin{array}{l}09-10- \\
20\end{array}$ \\
\hline 32 & 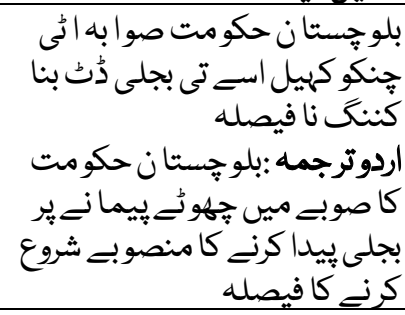 & $\begin{array}{l}\text { Represent } \\
\text { ative }\end{array}$ & $\begin{array}{l}09-10- \\
20\end{array}$ \\
\hline 33 & 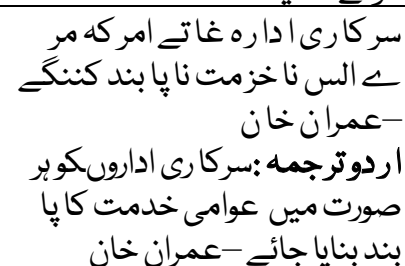 & Directive & $\begin{array}{l}09-10- \\
20\end{array}$ \\
\hline 34 & 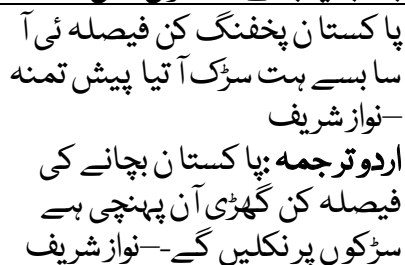 & $\begin{array}{l}\text { Commissi } \\
\text { ve }\end{array}$ & $\begin{array}{l}09-10- \\
20\end{array}$ \\
\hline 35 & 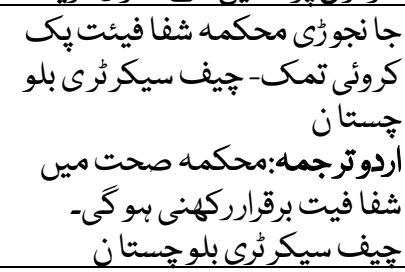 & $\begin{array}{l}\text { Commissi } \\
\text { ve }\end{array}$ & $\begin{array}{l}09-10- \\
20\end{array}$ \\
\hline 36 & 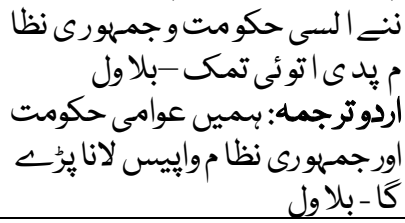 & $\begin{array}{l}\text { Commissi } \\
\text { ve }\end{array}$ & $\begin{array}{l}09-10- \\
20\end{array}$ \\
\hline 37 & 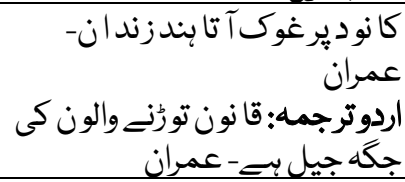 & $\begin{array}{l}\text { Expressiv } \\
\text { e }\end{array}$ & $\begin{array}{l}09-10- \\
20\end{array}$ \\
\hline 38 & 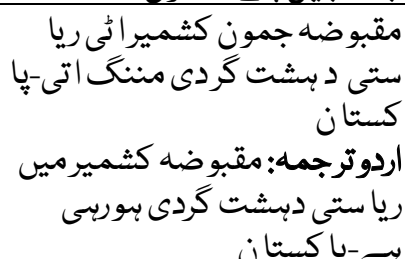 & $\begin{array}{l}\text { Expressiv } \\
\text { e }\end{array}$ & $\begin{array}{l}09-10- \\
20\end{array}$ \\
\hline
\end{tabular}

\begin{tabular}{|c|c|c|c|}
\hline 39 & 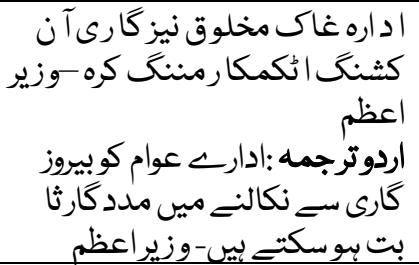 & $\begin{array}{l}\text { Expressiv } \\
\mathrm{e}\end{array}$ & $\begin{array}{l}09-10- \\
20\end{array}$ \\
\hline 40 & 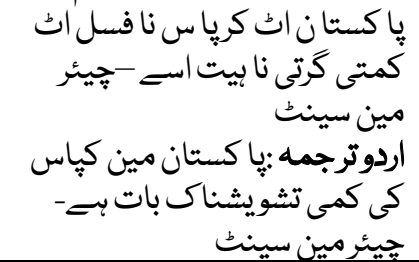 & $\begin{array}{l}\text { Expressiv } \\
\text { e }\end{array}$ & $\begin{array}{l}09-10- \\
20\end{array}$ \\
\hline
\end{tabular}

